\title{
UNFAIR DISMISSALS IN AUSTRALIA: DOES ARBITRATION HELP EMPLOYEES?
}

\author{
Dr. John Chelliah \\ Lecturer \\ School of Management \\ University Technology Sydney \\ PO Box 123 \\ Broadway NSW 2007 \\ Australia \\ Phone: +6129514 3624 \\ Fax: +61295143615 \\ Email: john.chelliah@uts.edu.au
}

\author{
Dr Brian D’Netto \\ Associate Professor and Program Director \\ International Graduate School of Business \\ University of South Australia \\ GPO Box 2471 \\ Adelaide SA 5001 \\ Australia \\ Phone: +61 383029156 \\ Fax: +6138302 0709 \\ Email: brian.dnetto@unisa.edu.au
}

Journal: Employee Relations

Total Words: $\quad \mathbf{5 , 4 8 4}$ 


\section{ABOUT THE AUTHORS}

Dr John Chelliah is a Lecturer in Industrial Relations at the University of Technology, Sydney, Australia. John spent more than two decades working in the field of Industrial Relations and Human Resources Management in industry. He completed his Ph.D. in Industrial Relations at RMIT University in Melbourne, Australia. His research interests include industrial relations and human resource management with a special focus on the international environment. He has presented papers at several international conferences.

Dr. Brian D’Netto is an Associate Professor and Program Director at the International Graduate School of Business, University of South Australia. Dr. D’Netto has a Ph.D. in Human Resource Management from the State University of New York at Buffalo, USA. He has published research papers in international refereed journals and has presented his research at national and international conferences. His current research interests include Recruitment and Selection, Training and Development, Performance Management, Compensation Systems, Employee Relations and Managing Workforce Diversity. 


\section{STRUCTURED ABSTRACT}

\section{Unfair Dismissals In Australia: Does Arbitration Help Employees?}

\section{Category}

Research Paper

Key Words: Award, Dismissal, Arbitration, Reinstatement, Unfair, Australia,

\section{Purpose}

To determine the factors associated with arbitration awards in unfair dismissal complaints under Australian federal legislation and to assess whether employees benefit from arbitration.

\section{Methodology}

This research involves an empirical analysis of 342 decisions in 17 industries by arbitrators in the Australian Industrial Relations Commission over the four year period 1997-2000. Logistic and ordinary least squares regression are used to analyse the data.

\section{Findings}

The findings of this study indicate that $50.6 \%$ of arbitration decisions were in favour of employees and only $10.8 \%$ of complainants were reinstated. Independent variables which are significantly associated with each of the three dependent variables are identified.

\section{Research Implications}

The results of this study enable researchers to gain a deeper understanding of the arbitration process and recognise independent variables that are associated with the arbitrator's decision in unfair dismissal cases.

\section{Practical Implications}

Employers lose half the unfair dismissal cases that go to arbitration. To reduce legal and associated costs, employers may need to look at ways of creating a more harmonious workplace. Employees do not benefit much from arbitration and have little chance of reclaiming their jobs. Reaching a settlement through mediation may be a better option.

\section{Originality/Value}

This is the first study to assess arbitration decisions in Australia. By developing a conceptual model based on arbitration outcomes and structuring the analysis on this model, the paper presents a logical understanding of the factors that drive arbitration decisions and remedies. 


\section{INTRODUCTION}

In a world of rapid organisational change, the right to continuous employment has become very precious. People build much of their lives around their jobs. Their incomes and prospects for the future are inevitably founded on the expectation that their jobs will continue. Thus, the consequences of dismissal are very tragic. For some employees, it may mean breaking up a community, uprooting homes and relocating families. Others, particularly older employees, may be faced with the greatest difficulty of finding another job (Report of the Donovan Royal Commission on Trade Unions and Employer Associations, 1965-78). Given the significant adverse impact of a dismissal, many employees in Australia have sought the help of arbitrators to reclaim their jobs. An unfair dismissal occurs when the termination of employment is considered to be unfair, harsh or unreasonable (Wallace-Bruce, 1999). The primary remedy for unfair dismissals in Australia is reinstatement. The grant of compensation is only a secondary remedy (section $170 \mathrm{CH}$ [3] of the Workplace Relations Act, 1996).

In Australia, three legal avenues cover unfair dismissals. The first legal avenue available is common law (Macken, O’Grady \& Sappideen, 1997). The courts are generally the avenue for senior managers (on an annual salary of over \$81,500 in 2002 and indexed annually) whose termination from employment is neither covered by a specific statute nor by a collective agreement (Grubb \& Naughton, 1992). The second legal avenue governing dismissal is Federal law. The Workplace Relations Act, 1996 conferred unfair dismissals jurisdiction on the Australian Industrial Relations Commission (AIRC). Commonwealth public sector employees, territory employees, employees of a constitutional corporation or engaged in interstate or overseas trade and most employees in the State of Victoria are covered under Federal law (Lawrence, 1998). The third legal avenue arises from the 
provisions of the Workplace Relations Act, 1996 which sends non-federal award employees back to their state jurisdictions with the exception of Victoria which transferred most of its industrial power to the Commonwealth in 1996 (Wheelwright, 1999).

The scope of this study is limited to the second legal avenue, that is unfair dismissals under the Workplace Relations Act, 1996. This paper examines whether employees in Australia have actually benefited from the arbitration process. This study seeks to gain an insight into how the Commissioners of the Australian Industrial Relations Commission, in their capacity as arbitrators, exercised arbitral jurisprudence in the course of interpreting the unfair termination provisions of the Workplace Relations Act, 1996.

\section{FEDERAL LEGISLATION ON UNFAIR DISMISSALS}

In Australia, federal unfair dismissal provisions had been in operation from March 1994, when Parliament under the Labour Government amended the Industrial Relations Act, 1988 by passing the Industrial Relations Reform Act 1993 with a new Part VIA relating to termination of employment (Blackford, 1999). These amendments contained the most comprehensive protections against unfair dismissal ever seen in Australia (Howell, 1998).

In March 1996, the current Liberal Government was elected, replacing the Labour government. Within nine months, the Workplace Relations Act, 1996 was approved. This legislation introduced major changes to federal law relating to protection of employees against unfair dismissal, including further restricting the already limited relief available to employees who have been unfairly dismissed (Lawrence, 1998). It further empowers the commissioners of the AIRC 
to arbitrate on matters of unfair dismissal matters. In arbitration of an unfair dismissal claim, the arbitrators can order reinstatement, re-employment to another position, or payment of compensation (Macken, O’Grady \& Sappideen, 1997).

Many workers have been excluded altogether from the operation of the Workplace Relations Act, 1996. These factors are reflected in the drastic reduction in the number of applications for relief under federal legislation since the Workplace Relations Act, 1996 came into effect. In the period from 31 December, 1996 to 3 October, 1997, 5222 federal unfair dismissal applications were made, compared with 11,196 applications in the preceding year (Howell, 1998). This represents a 51\% decline. It may be argued that this was the primary objective of this legislation. It is worth noting that not all complaints proceed to arbitration. A good number are discontinued, others are turned down by the Australian Industrial Relations Commission due to lack of merit (for example outside the prescribed time limit for application), while others are settled during mediation provided by the Australian Industrial Relations Commission. Only a fraction of the applications proceed all the way to arbitration.

\section{RESEARCH ON UNFAIR DISMISSALS}

Relatively little research has been conducted in the area of unfair dismissals, even though claims against unfair dismissals form a significant portion of employee grievance arbitration. American studies have been excluded from this review, as case studies from the U.S.A. do not fit the legal or arbitral framework of this study. The doctrine of employment-at-will provides the overarching legal basis for the employment relationship in the U.S.A. Employment-at-will assumes that employees and employers have equal bargaining power over each other and that government 
intrusion into the activities of free agents is unnecessary and unwelcome (Meggiorin, 1997). American workers receive very little protection against unfair dismissal from their jobs. Wrongful discharge, as part of the public policy exception to employment-at-will, has been and continues to be a very grey area of the law. Generally, studies of the arbitral scene from the British Commonwealth countries with close common legal foundations such as the United Kingdom, New Zealand and Canada are good comparisons for Australia. However, the few studies in these countries have confined themselves to a limited number of variables affecting arbitration decisions and generally lack statistical rigour.

Goodman, Earnshaw, Marchington and Harrision (1998) conducted a study funded by the British Department of Trade and Industry. This research included factors influencing the incidence, or otherwise, of unfair dismissal cases. The research is based on matched comparisons of predominantly small businesses or sites in three industries i.e., Hotel and Catering, Transport and Communications, and Engineering. The authors reviewed disciplinary procedures in these industries and examined some of the major influences such as recruitment practices and management styles and methods on the operations of these businesses. The study included data of published cases arbitrated by industrial tribunals covering the period 1975 to 1997. In total 36 cases (12 in each industry) were studied. This essentially qualitative research was unable to point to a single variable which might readily explain the incidence of contested unfair dismissal claims. These researchers concluded that in addition to the influences of the procedural approach, the style and methods adopted by managers, the respect they commanded among employees and their consistent application of normative standards shared with employees seemed to be important. 
Boon (1992) conducted a study in New Zealand which included 597 cases covering both union and non-union sector employees for a five-year period (1987-1991). This study consisted of both arbitration and court decisions. Boon (1992) found that 51 per cent of employees were successful in their action against their employers. This research covered only issues relating to substantive reasons and procedural fairness but did not undertake a study of remedies awarded to successful complainant employees in contrast to Eden's (1990) study which included this dimension. Chelliah (1998) examined 136 employment court decisions in New Zealand over a seven-year period including both union and non-union sector employees. Only 27 per cent of dismissals were found to be justified while 73 per cent were unjustified. Chelliah (1998) analysed procedural fairness and substantive aspects of all cases. However, this study did not research the remedies awarded to successful complainant employees.

Eden (1990) studied 395 non-union cases in Canada covering a eleven-year period from 1979 to 1989. These cases were decided under Canadian federal jurisdiction. This study found that arbitrators upheld 34 per cent of employers' dismissal decisions and 27 per cent of complainant employees were reinstated. The dependent variables in this study were "complaints sustained or denied” and remedies that flow from a complaint from an employee being upheld, that is, reinstatement and damages for suspension (the period between employee's termination and reinstatement). Eden's (1990) research included as independent variables, the impact of employees' characteristics/actions as well as employers' characteristics and actions on the ultimate decision of the arbitrators. 
There is a dearth of similar research on unfair dismissals in Australia. In spite of reliable sources of primary dismissal case data being available, for example the free online data available from the Australian Legal Information Institute and the Australian Industrial Relations Commission web sites, rigorous research has not been undertaken. The current study seeks to fill this gap in the literature by focusing on the area of unfair dismissals under the current federal legislation (Workplace Relations Act, 1996). There is some anecdotal evidence that the present legislation is far less employee-friendly than its predecessor, the Industrial Relations Reform Act, 1993. It would be useful to determine what approach arbitrators take when considering the appropriate remedy for proven unfair dismissal. It is important to gain an understanding of the circumstances that lead to an award of reinstatement as opposed to monetary compensation. Where reinstatement is ordered, what length of suspension is compensated? This is another key question. Whenever monetary compensation is awarded, what factors influence the approach taken by the arbitrators? How is the quantum of monetary compensation reached? This research attempts to provide answers to these questions using statistical analysis of data to provide a better understanding of arbitrators' decisions.

\section{VARIABLES INCLUDED IN THIS STUDY}

In order to gain a deeper understanding of the arbitration process, an extensive review of the literature was carried out (Boon, 1992; Chelliah, 1998; Eden, 1990; Goodman, Earnshaw, Marchington \& Harrision, 1998). Based on this review as well as written decisions of arbitrators of the AIRC, both dependent and independent variables were identified and tested in this study. 


\section{Dependent Variables}

The conceptual model as displayed in Figure 1 indicates that an analysis of the arbitration process with respect to unfair dismissals and remedies require investigation covering three dependent variables which are based on the outcomes of arbitration. The first dependent variable, award, measures whether the complaint of unfair dismissal by the employee was upheld or denied by the arbitrator. The second dependent variable, damages, measures the weeks of remuneration awarded to those employees who are reinstated. The third dependent variable, compensation, measures the weeks of remuneration awarded to those employees whose complaints were upheld but were not reinstated.

\section{“Take in Figure 1"}

\section{Independent Variables}

The independent variables are derived primarily from the literature on factors which are taken into consideration by arbitrators when arriving at a decision (Chelliah, 1998; Eden, 1990). In addition, variables were also included based on the principles of 'just cause' under common law (Davies \& Freedland, 1984), ‘fair dismissal’ under section 170 CG(3) and 'appropriate remedy’ under $170 \mathrm{CH}(2)$ of the Workplace Relations Act, 1996.

Independent variables likely to be associated with the first dependent variable, reward, can be categorised according to the type of offence, employee characteristics and employer characteristics. Replicating Eden’s (1990) study, twelve independent variables were identified and included in the type of offence category. These variables may either mitigate or aggravate 
the seriousness of a particular offence (Eden, 1990). The second category, employee characteristics, include past record, length of service, lack of intent in committing the offence, willingness to accept fault for the wrong-doing, isolated incident of misconduct, special compassionate or economic circumstances, rehabilitation potential, absence of pre-meditation and position in the organisation. The third category, employer characteristics, include the application of progressive discipline, failure to administer warnings, absence of a culminating incident, improper work rules, unequal treatment, provocation, condonation and lack of procedural fairness.

Independent variables expected to be associated with second dependent variable, damages, include length of service, reinstatement requested by complainant, gender, employee's profession, compassionate circumstances present, remorse, conflict between employer and complainant, complainant's job abolished, difficulty in finding another job, employment relationship broken down, labour market conditions, period of suspension, mitigation of losses, complainant at fault and new job after dismissal.

Independent variables which are likely to be associated with the third dependent variable, compensation, include years of service, gender, employee's profession, new job after dismissal, difficulty in finding another job, time-lapse between discharge and award, labour market condition, mitigation of losses and complainant at fault. 


\section{METHODOLOGY}

Data for empirical analysis was collected from unfair dismissal case decisions rendered by arbitrators of the Australian Industrial Relations Commission. These cases on unfair dismissals were obtained from the on-line AustLII Databases. This site on the internet is hosted by the Australian Legal Information Institute (AustLII) and provides a free database of cases determined by the Australian Industrial Relations Commission.

Decisions dealing solely with the preliminary objections regarding the Australian Industrial Relations Commission's jurisdiction to hear the case or extension of time applications was excluded from the study. Such jurisdictional issues include disputes as to whether complainants met the eligibility requirements of the statutory protection. 684 cases of arbitration decisions ranging in length from 25 to 75 pages each, comprised the total population for this study.

With this aim, every second case listed in each industry grouping was selected for analysis. In other words, 50 per cent of all cases in each industry grouping were selected for analysis. The final sample included in this study consisted of 342 cases from 17 industries. Both logistic and ordinary least squares regression were used to analyse the data.

\section{FINDINGS AND ANALYSIS}

\section{Award by the Arbitrator}

The analysis begins with the first dependent variable, award, that is whether a complaint was upheld or denied and the predictor variables associated with the decisions of arbitrators to uphold or deny the employee complaints. Out of the 342 cases for the four year period 1997 to 2000, 
$50.6 \%$ of the complaints were upheld, that is the arbitrators ruled in favour of the employee. It appears that overall both employees and employers had an equal chance of winning their cases in the four years covered by this study. Out of the total of 173 employees who were successful in having their complaints upheld, 37 were reinstated whilst 136 were awarded compensation only. In other words, only $10.8 \%$ of complainants were reinstated.

Additional analysis of the data indicated that the most frequent offences for employees were violation of rules, abandonment of work, unsatisfactory performance and incompatibility with other employees or supervisors. Nearly two-thirds (66.1\%) of the employees had no previous record of being disciplined.

Logistic regression was used to identify significant independent variables in relation to the first dependent variable, award, (that is employee's complaint being upheld or denied). Logistic regression was used since the dependent variable was binary or dichotomous (Morgan \& Griego, 1998). Award was coded 1 if the employee's complaint was upheld and 0 if the complaint was denied. Table 1 confirms that there are only 5 significant predictors of awards. These predictors are dishonesty, years of service, failure to apply progressive discipline, failure to provide warnings and improper promulgation of rules.

\section{“Take in Table 1"}

In table 1, the value of $\operatorname{Exp}(B)$ gives the "odds ratio", which is the increase (or decrease if the ratio is less than one) in odds of being in one outcome category when the value of the predictor increases by one unit (Tabachnick \& Fidell, 2001). Odds ratios of greater than 1 show the 
increase in odds of an outcome of 1 (the 'response' category) with a one-unit change in the predictor. In this model, for the dependent variable, award, interpretation of the results are as follows:

- The predictor 'Dishonesty'(Exp(B) of 9.30) indicates that where an employee was found to be dishonest, the odds of the complaint being declined rather than upheld are over 9 times as much as where an employee was not dishonest;

- The predictor 'Years of Service' $(\operatorname{Exp}(B)$ of 1.07) indicates that where an employee was found to have more years of service, the odds of the complaint being upheld rather than declined was 1.07 times as much as where an employee had less service;

- The predictor 'failure to apply progressive discipline' indicates that where the employer fails to carry out progressive discipline, the odds of the employee's complaint being upheld increases by $98.5 \%$ (1-.015);

- The predictor 'failure to provide warnings' indicates that where an employer fails to warn an employee of unsatisfactory performance, the odds of the employee's complaint being upheld increases by $97.1 \%$ (1-.029); and

- The predictor 'improper promulgation of rules' indicates that where there is improper promulgation of workrules by the employer, the odds of the employee's complaint being upheld increases by $97.3 \%(1-.027)$. 
These are interesting statistics as they give an indication of the predictors that are highly likely to affect the decision-making of an arbitrator in relation to upholding or denying an employee's complaint. Dishonesty by an employee is almost certain to swing a decision in favour of the employer. However, in cases where the employee had a long period of service or when the employer failed to apply progressive discipline, warn the employee about unsatisfactory performance and adequately promulgate work rules, the decision of the arbitrator was likely to be in favour of the employee.

\section{Damages for Employees Reinstated}

The second dependent variable is damages (measured in weeks of remuneration) awarded to those employees who were reinstated. In total 37 employees out of the 173 employees who were successful in having their complaints upheld, were reinstated. Damages awarded by arbitrators usually covered the period for which the employee was suspended from work (mean $=17.57$ weeks). However, reduced damages were awarded if the employer had already paid compensation to the employee prior to termination or the employee was culpable to a certain extent.

Regression analysis for the second dependent variable, damages, indicates that only one independent variable was significant. Period of suspension had a significant, positive relationship with damages ( $\beta=.77, \mathrm{p}<.001$ ) (see Table 2). The results indicated that as the time interval between dismissal and reinstatement increases, damages awarded are likely be higher.

"Take in Table 2" 


\section{Compensation for Employees not reinstated but complaints upheld}

The third and final dependent variable is compensation (measured in weeks of remuneration) awarded to those employees whose complaints were upheld but were not reinstated. In total, 136 out of the 173 employees who were successful in having their complaints upheld, were awarded compensation only. In other words, more than three-fourth (78.6\%) of employees who had their complaint upheld, were not reinstated.

Analysis of the data indicates that there is practically no correlation between the waiting time and compensation awarded. While the mean waiting time between termination and the decision of the arbitrator was 36.45 weeks, the mean compensation awarded was 13.21 weeks wages. In some cases the arbitrator awarded the maximum of 26 weeks as prescribed in the legislation, while in other cases damages seem to have been awarded based on the merits of the case.

Regression analysis for compensation (measured in weeks of remuneration awarded) indicates that only two predictors are significant. 'Years of Service' had a significant, positive relationship with compensation $(ß=.23, \mathrm{p}<.01)$ while 'Complainant is at fault' had a significant, negative relationship with compensation $(ß=-.39, \mathrm{p}<.001$ ) (see Table 3). These results indicate that arbitrators are likely to award more compensation to employees who have longer periods of service with the employer. However, when the complainant is at fault, arbitrators are likely to award less compensation.

“Take in Table 3” 


\section{DISCUSSION}

This study focused on arbitration awards with respect to unfair dismissal complaints in Australia. This research specifically examined the independent variables that are associated with arbitration awards, damages and compensation. The study found that dishonesty, years of service, failure to apply progressive discipline, failure to provide warnings and improper promulgation of rules are associated with arbitration awards. The results also indicate that the period of suspension is associated with damages awarded to employees who are reinstated. In addition the employee's period of service and culpability are associated with the amount of compensation awarded.

The results of this study have significant implications for employers and employees. Given that more than half (50.6\%) of unfair dismissal complaints by employees were upheld by arbitrators, it could be said that from the employer's perspective, unnecessary expenditure may have been incurred from the date of termination to the date of the decision of the arbitrator. This expenditure may have been incurred in the form of legal advice and representation, time of staff involved, etc. The results of this study also indicate that damages awarded increases with the period of suspension. In addition, the pending action may cause adversity towards the employer by existing staff and unions. The cost of this adversity while not easily quantifiable in dollar terms, is likely to have a negative impact on morale, productivity and the quality of employee relations in the workplace.

No doubt, factors other than merit, may influence the parties to proceed to arbitration. However, it is reasonable to assume that the probable outcome is an important consideration in making that 
decision. Accordingly, it could be argued that in light of the fact that $50.6 \%$ of complaints were upheld, a change in employer industrial relations practices is necessary, especially if employers desire a more harmonious workplace.

Given that the research shows some measure of predictability in terms of the factors considered by arbitrators in making their decisions, there may be strategic implications for the way employers respond to employee misconduct in the workplace. To some extent, arbitrator decisions may force employers into reshaping processes that relate to performance management, discipline and termination. Specifically, employer response to an employee's wrongdoing should include consideration of the nature of the offence, the employee's record and the length of service, before resorting to dismissal. The employer must observe the statutory requirements of section $170 \mathrm{CG}(3)$ and this is best met by administering a fair and robust system of progressive discipline. One area requiring improvement is the necessity to sufficiently document warnings, provide counselling and necessary training for employees, so that they can attain the standards expected by the employer. Employers must make the necessary policy changes to ensure that supervisors/managers are trained in the administration of progressive discipline. Compliance with policy needs to be constantly monitored by employers as well.

An important point to recall is that the number of dismissed employees who actually pursued unjust dismissal complaints under this legislation is unknown. If it is a small proportion, employers may well weigh the risk of arbitration against any major change in practices. Another factor to be considered in weighing the risk of arbitral intervention in the decision to dismiss, is the number of cases that are settled prior to arbitration. As this information is unavailable, it is 
difficult to advise employers on the overall picture of unfair dismissals. It is suggested that employers seek alternative mechanisms to arbitration to alleviate the considerable time delays in arbitration decisions. Such alternative mechanisms could be to establish an internal employeeemployer committee consisting of people with more in-depth knowledge of the workplace than third party arbitrators who have little knowledge of the dynamics of a particular workplace.

Statutory protection under the Workplace Relations Act, 1996 also has important implications for employees covered under this legislation. For employees, offences such as dishonesty reflect badly in the eyes of arbitrators. Long serving employees can expect their length of service to be taken into consideration in the calculation of compensation. Where employers fail to apply progressive discipline or where there is improper promulgation of work rules by the employers, employees can expect a favourable decision from the arbitrator. This study clearly shows that the Workplace Relations Act, 1996 unlike its predecessor (Industrial Relations Reform Act, 1993), has lead arbitrators to treat procedural fairness as a technical irregularity, thereby reducing protection to employees. The empirical analysis shows that lack of procedural fairness is clearly not a significant factor in influencing the decision of the arbitrator. This confirms earlier suspicions by legal experts such as Chief Justice Murray Wilcox that the Workplace Relations Act will denigrate the traditional importance of procedural fairness in the process of fair dismissal of employees (Wilcox, 1997). Employees cannot rely on lack of procedural fairness by employers to be a factor that would influence arbitrators' decisions in their favour. Employees may wish to lobby their politicians and unions to restore the importance of procedural fairness in future legislation or even incorporate it into employment contracts such as enterprise agreements and Australian Workplace Agreements. 
From an employee's perspective, the findings of this study indicate that arbitration does not really bring significant benefits. While $50.6 \%$ of arbitration decisions were in favour of employees, only $10.8 \%$ of the total complainants were reinstated and received damages. The mean amount of damages awarded was only equal to 17.57 weeks wages. Although, the Workplace Relations Act, 1996 retains reinstatement as the primary remedy, it is sad to note that there is very little chance of employees actually reclaiming their jobs. The fact that $78.6 \%$ of successful complainants were granted only a relatively low amount of compensation (mean of 13.21 weeks wages) seems to indicate that arbitrators continue to resort to the common law remedy of damages or compensation rather than reinstatement. Even though the maximum amount of damages or compensation prescribed under the Workplace Relations Act, 1996 is the equivalent of 26 weeks wages, arbitrators have on average awarded only half this amount, even when the employee was not going to be reinstated.

Finally, the tendency to award monetary compensation far more frequently than reinstatement could be viewed as a deficiency in the arbitral regime from the employee's perspective. The unavailability of reinstatement as a remedy was seen as a major deficiency of the common law regime. Statutory protection was intended to bridge this gap by providing reinstatement as a primary remedy. However, if arbitrators overwhelmingly rule against reinstatement, one wonders whether the letter of the law differs from law that is actually dispensed in Australia. 


\section{REFERENCES}

AIRC 2001 (Online) http://www.airc.gov.au/procedures/rules/ruleshtml.

AustLII Databases (Online) http://www.austlii.edu.au/cases/cth/IRCommA/toc-1987.html

Blackford, R. 1999, "Unfair Dismissal Law and the Termination of Contracts for Specified

Periods of Time", Australian Journal of Labour Law, vol. 12, no. 3, pp. 217-20.

Boon, B. 1992, "Procedural Fairness and the Unjustified Dismissal Decision", New Zealand Journal of Industrial Relations, vol. 17, no. 3, pp. 301-317.

Chelliah, J. 1998, Procedural Fairness and the Unjustified Dismissal Decision: A Study of Unjustifiable Dismissal Cases Heard by the Courts for the Period 1991 to 1997 under the Employment Contracts Act 1991. Master's thesis submitted to Massey University, Auckland.

Davies, P. and Freedland, M. 1984, Labour Law: Text and Materials, 2nd ed, Weidenfeld \& Nicolson, London.

Eden, G. 1990, Unjust Dismissal in the Canadian Federal Jurisdiction, PhD Thesis submitted to School of Graduate Studies, University of Toronto, Toronto.

Goodman, J., Earnshaw, J., Marchington, M. and Harrison, R. 1998, Unfair Dismissal Cases, Disciplinary Procedures, Recruitment Methods and Management Style. University of Manchester.

Grubb, I., and Naugton, R. 1992, "Unfair and Wrongful Dismissal: Recent Developments", Law Institute Journal, vol. 66, pp. 913-915.

Howell, C. 1998, "Unfair Dismissals under the Workplace Relations Act 1996", Alternative Law Journal, vol. 23, no. 2, pp. 63-66.

Industrial Relations Act, 1988 (Cth)

Industrial Relations Reform Act, 1993(Cth)

Lawrence, B. 1998, " The Law of Unfair Dismissal: 1983-1998", Law Institute Journal, vol. 72, no.6, pp.51-53.

Macken, J. J., O'Grady, P. and Sapiddeen, C. 1997, The Law of Employment, 4th Edition, LBC Information Services, Sydney.

Meggiorin, H. 1997, "Proving Misconduct in Order to Justify Dismissal under the Workplace Relations Act (Cth)", Corporate and Business Law Journal, vol. 10, no. 2, pp. 163-205. 
Morgan, G. A. and Griego, O. V. 1998, Easy Use and Interpretation of SPSS for Windows, Mahwah, New Jersey.

Report of the Donovan Commission on Trade Unions and Employer Associations 1965-78, HMSO, UK.

Tabachnick, B. G. and Fidell, L. S. 2001, Using Multivariate Statistics, 4th edition, Allyn and Bacon, Boston.

Wallace-Bruce, N. L. 1999, Outline of Employment Law, 2nd edn, Butterworths, Chatswood.

Wheelwright, K. 1999, Labour Law, Butterworths, Chatswood.

Workplace Relations Act, 1996 (Cth)

Workplace Relations and Other Legislation Amendment Act, 1997 (Cth)

Wilcox, M. 1997, " Dismissal: A Fair Go All Round?" in Workplace Relations, eds Lee, M. and Sheldon, P., Butterworths, North Ryde.

\section{Acknowledgement}

The authors are grateful to statisticians Dr. Ken Matawie of University of Western Sydney and Associate Professor Peter Petocz of Macquarie University for their advice and guidance in relation to the use of statistical models and SPSS program. 
FIGURE 1

Conceptual Model of Arbitration Outcomes

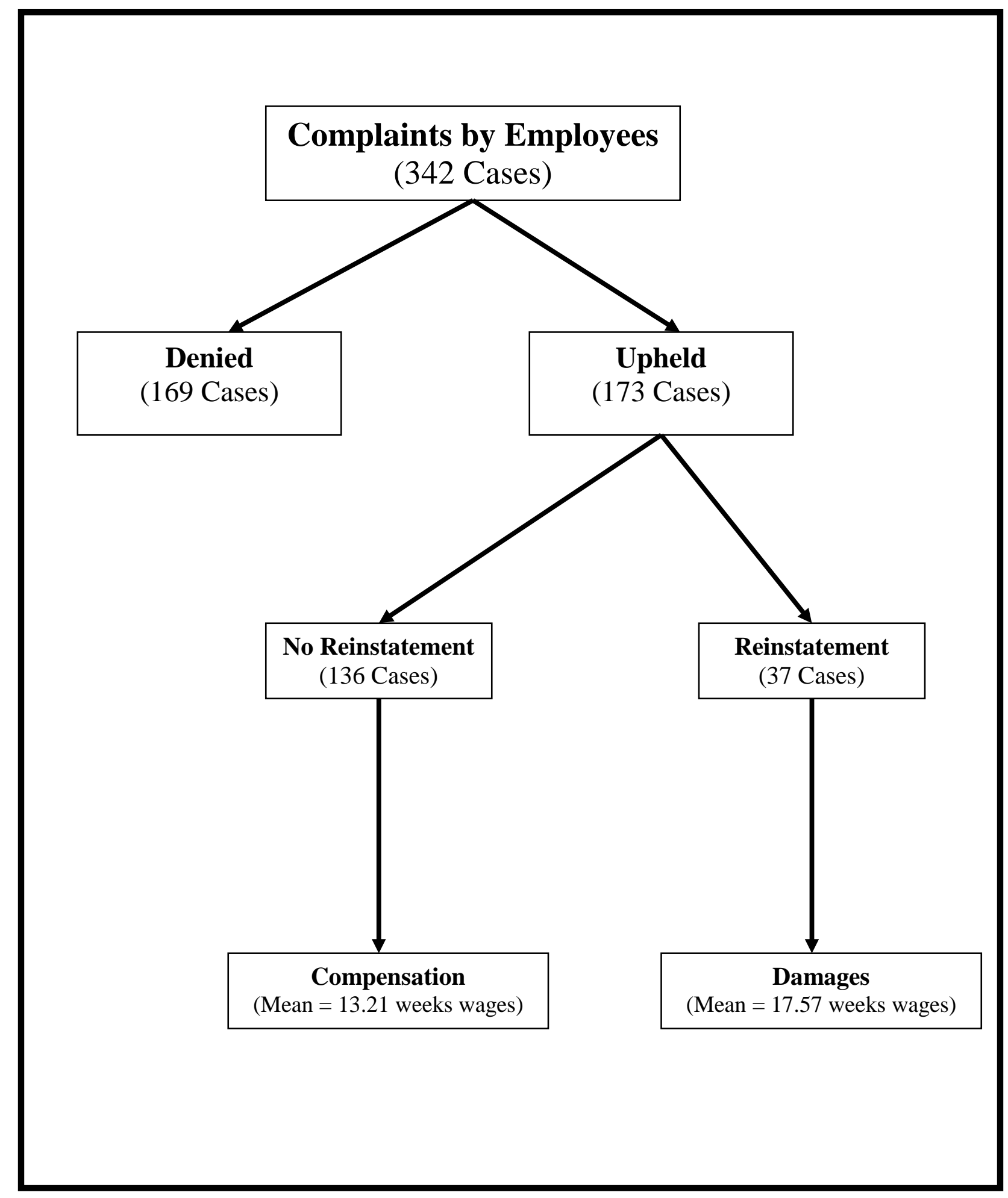


TABLE 1

Results of Logistic Regression Analysis for Award

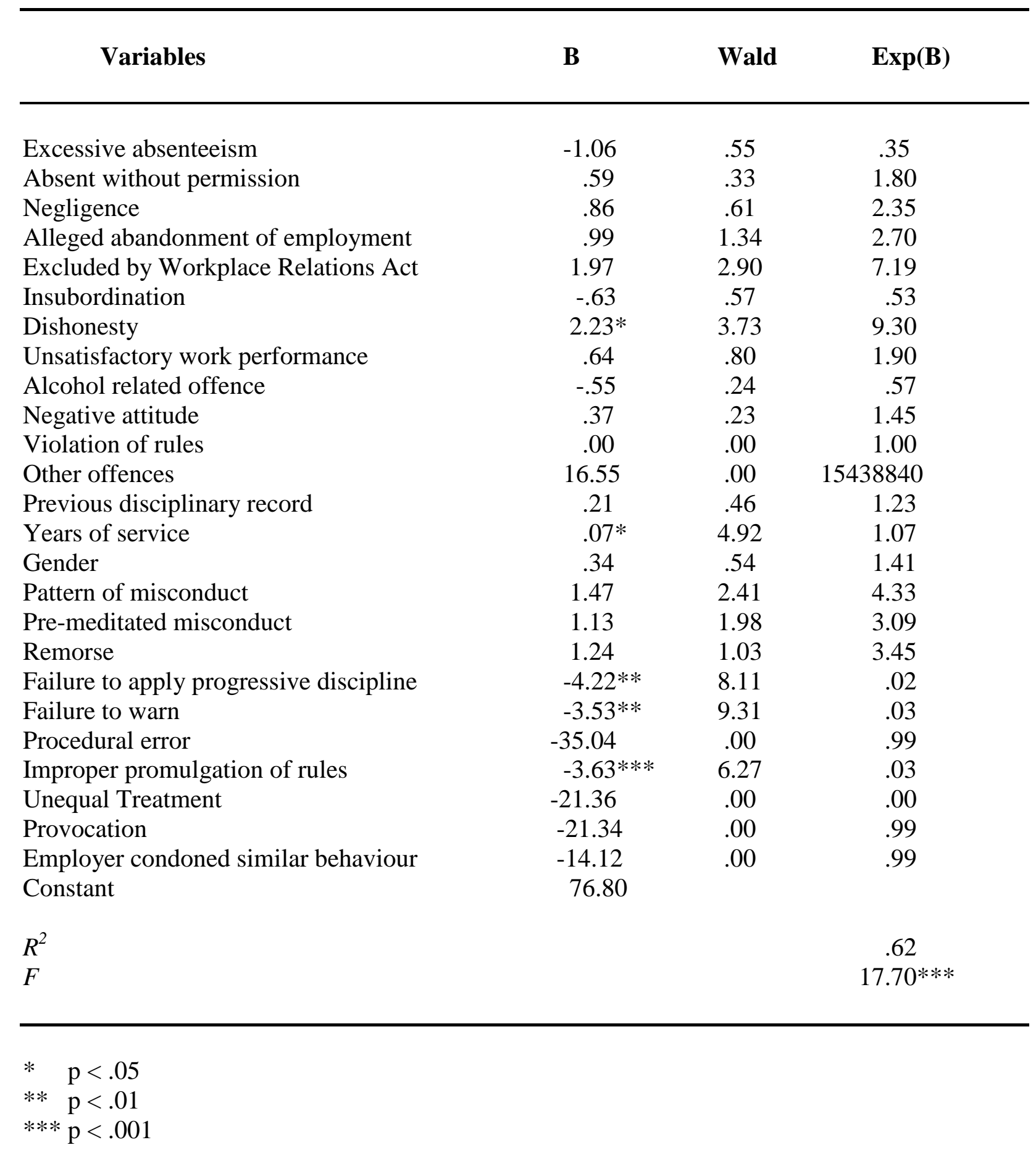


TABLE 2

Results of Regression Analysis for Damages

Variables

Years of service

Reinstatement requested by complainant

Gender

Employee's profession

Compassionate circumstances present

Remorse

Conflict between employer and complainant

Complainant's job abolished

Difficulty in finding another job

Employment relationship broken down

Labour market condition

Period of suspension

Mitigation of losses

Complainant at fault

New job after dismissal

$R^{2}$

F

$\mathrm{p}<.05$

$* * \quad \mathrm{p}<.01$

$* * * \mathrm{p}<.001$
Beta

$-.22$

$-.17$

.25

.08

.12

$-.31$

.04

$-.23$

$-.09$

$-.10$

.22

$.77 * * *$

.17

.24

$-.39$

.59

2.05* 
TABLE 3

Results of Regression Analysis for Compensation

Variables

Years of service

Gender

Employee's profession

New job after dismissal

Difficulty in finding another job

Time lapse between discharge and award

Labour market condition

Mitigation of losses

Complainant at fault

$R^{2}$

F

$* \quad \mathrm{p}<.05$

$* * \quad \mathrm{p}<.01$

$* * * \mathrm{p}<.001$
Beta

$.23 * *$

$-.02$

$-.02$

$-.05$

.03

.07

.16

.13

-.39***

.23

$4.12 * * *$ 